\title{
Discretion of Member States vis-À- vis Public Security: Unveiling the LABYRINTH OF EU MIGRATION RULES
}

\author{
Václav Stehlík ${ }^{1}$ \\ Faculty of Law, Palacký University Olomouc, Czech Republic \\ vaclav.stehlik@upol.cz
}

STEHLÍK, Václav. Discretion of Member States vis-à-vis Public Security: Unveiling the Labyrinth of EU Migration Rules. International and Comparative Law Review, 2017, vol. 17, no. 2, pp. 127-142. DOI 10.2478/iclr-2018-0019.

\begin{abstract}
Summary: The article focuses on the public security exception as it is used in EU migration law. It opens with the public security grounds as they appear in the EU internal market rules and consequently in EU external relations. A special attention is paid to public security restrictions under the Directive 2004/114 as it was interpreted in case Fahimian. The article adds a comparison to other documents in EU external relations and their referrals to public security. The main perspective is the discretion attributed to Member States and their authorities when they apply public security exception especially in relation to regular migration.
\end{abstract}

Keywords: free movement of persons, immigration, public security, public policy, Directive 2004/114, Europe Agreements, European Economic Area, CETA

\section{Introduction}

The immigration and public security are highly sensitive topics for the EU as well its Member States. This has become increasingly visible especially during the EU migration crisis; however, the public security concerns are not limited to the irregular migration. The following analysis will focus on the concept of public security in the EU law and its interpretation in relation to various categories of migrants. It will cover particularly the third country nationals who are covered by EU secondary legislation (especially students from third countries) as it is reflected in most recent developments, namely the decision of the European Court of Justice (CJEU) in Fahimian. ${ }^{2}$ It will also comparatively refer to the grounds of public security as they appear in other EU external relations instruments. The main focus will be the extent of discretion left to Member States.

1 Associate professor and Jean Monnet Chairholder in EU law, Department of International and European Law, Faculty of Law, Palacký University in Olomouc, Czech Republic, e-mail:vaclav.stehlik@upol.cz. This article was prepared under the research project of the Czech Grant Agency, "Postavení osob ze třetích zemí v právu Evropské unie”, No.17$24822 \mathrm{~S}$.

2 C-544/15 Fahimian, ECLI:EU:C:2017:255.

Published by Palacký University Olomouc, Czech Republic, 2017. ISSN (print): 1213-8770; ISSN (online): 2464-6601 


\section{Concept of public security in EU law}

\subsection{Public security in the internal market: basic principles}

The public security exception is regulated within the EU internal market. It appears in provisions on the free movement of goods, ${ }^{3}$ workers, ${ }^{4}$ establishment,${ }^{5}$ capital $^{6}$ and services. ${ }^{7}$ It is thus, next to public policy, a common exception to all four market freedoms. There are other provisions related to public security which have not been interpreted by the CJEU yet and, thus, any practical evaluation of public security concerns is limited to internal market rules. ${ }^{8}$

The public security cannot be regarded as a general and self-standing recourse for Member States when they, even for a good security reason, do not intend to apply the EU law in full. The CJEU made it clear that any justification on public security grounds must strictly rest on an individual legal basis.9 The EU provisions on four freedoms do not give a definition of public security, and, any details or directions to Member States how to use it in their legislation and interpret it in national disputes are left to the interpretation of the CJEU. As a detailed analysis of the judicial developments has been done elsewhere ${ }^{10}$ at this place it suffices to make more general conceptual remarks and delineate principles formulated in the case-law.

The basic principles were set up in cases delivered in relation to the free movement of goods. Accordingly public security exception covers goods of fundamental importance for a country's existence which are crucial not only for its economy but especially for its institutions, essential public services and even the survival of its inhabitants. ${ }^{11}$ Any restrictions based on public security cannot be used for economic ends ${ }^{12}$ and a country cannot plead economic difficulties
Art. 36 TFEU.
Art. 49 TFEU.
Art. 52 TFEU.
Art. 65 TFEU.
Art. 52 in combination with art. 62 TFEU.

8 Namely art. 347 enables Member States to adopt measures in case of serious internal disturbances, war, serious international tension with a threat of war, or to carry out obligations accepted for the purpose of maintaining peace and international security.

9 222/84 Johnston v Chief Constable of the Royal Ulster Constabulary, ECLI:EU:C:1986:206, point 26.

10 STEHLÍK, Václav. Metamorphosis of Public Security Exception in the EU Internal Market and EU Citizens' Rights. In: Agnieszka Bień-Kacała, Lóránt Csink, Tomasz Milej, Maciej Serowaniec (ed.). Liberal constitutionalism - between individual and collective interests. Toruń: Wydział Prawa i Administracji Uniwersytetu Mikołaja Kopernia w Toruniu, 2017, p. 237-277.

11 72/83 Campus Oil, ECLI:EU:C:1984:256, point 34.

12 Similarly in the context of third country nationals see also art. 6, para 2 of Directive 2003/109/EC of 25 November 2003 concerning the status of third-country nationals who are long-term residents, OJ L 16, 23.1.2004, p. 44-53. 
caused by the elimination of barriers to trade in the EU. ${ }^{13}$ The public security covers both a Member State's internal and external security. ${ }^{14}$ The strict reading was confirmed also in the external dimension of trade and the CJEU refused that the concept of public security would be different and would allow a broader discretion of Member States. Consequently, the CJEU ruled in favour of parallelism in this regard. ${ }^{15}$

\subsection{Public security within the EU citizenship rules}

Even though the free movement of goods and common commercial policy lack the personal dimension, the general approach and principles seem to be transferrable also to other freedoms. This conclusion is supported by the practice of the CJEU that refers to its case law delivered across freedoms including the freedom of establishment ${ }^{16}$ and, above all, the free movement of workers. In these areas the CJEU also interprets public security exception in a restrictive manner with a stress on the non-discrimination based on nationality.

After the introduction of the EU citizenship common principles became applicable to all free moving citizens. It was particularly the EU citizenship that brought in a new ideological shift as the economic status is not crucial anymore for setting up the right of residence. It is based on the civis europeus sum perspective $^{17}$ which brings in a complex set of questions on non-discrimination, proper justification of restrictions including public policy and public security. The currently applicable Directive $2004 / 38^{18}$ formulated common rules with

13 See art. 36 TFEU and Campus Oil, point 35 or C-398/98 Commission of the European Communities v Hellenic Republic, ECLI:EU:C:2001:565, points 30-31.

14 See C-367/89 Richardt, ECLI:EU:C:1991:376, point 22.

15 C-70/94 Werner v Bundesrepublik Deutschland, ECLI:EU:C:1995:328, point 25.

16 C-423/98 Albore, ECLI:EU:C:2000:401.

17 In that regard it was used even before the introduction of EU citizenship at the beginning of 90 s by AG Jacobs in C-168/91 Konstantinidis v Stadt Altensteig and Landratsamt Calw, ECLI:EU:C:1992:504. The EU citizenship was accepted as a fundamental status of all free moving EU citizens in the CJEU's decision in C-184/99 Grzelczyk, ECLI:EU:C:2001:458. This principle was strongly evident in ground-breaking cases concerning its application in situations with no actual cross-border element in the national process of granting national and consequently also EU citizenship; for a recent analysis see also LENAERTS, Koen. 'Civis europaeus sum': from the cross-border link to the status of citizen of the Union. Online Journal on Free Movement of Workers within the European Union, 2011, no 3, p. 6-17.

18 Directive 2004/38/EC of the European Parliament and of the Council of 29 April 2004 on the right of citizens of the Union and their family members to move and reside freely within the territory of the Member States amending Regulation (EEC) No 1612/68 and repealing Directives 64/221/EEC, 68/360/EEC, 72/194/EEC, 73/148/EEC, 75/34/EEC, 75/35/EEC, 90/364/EEC, 90/365/EEC and 93/96/EEC (Text with EEA relevance), OJ L $158,30.4 .2004$, p. $77-123$; see esp. points 23 and 24 of the preamble, and art. 28 of the Directive. 
strict conditions for expulsion of EU citizens and their family members residing in another Member State irrespective of their economic status.

A central rule inserted in the secondary legislation ${ }^{19}$ is the requirement of personal conduct the harmfulness of which must be proved before any expulsion order may be issued. Furthermore, the CJEU put an emphasis on the nondiscriminatory assessment of the same conduct and there is a volume of cases decided since 60 s where after an initial reluctance ${ }^{20}$ the CJEU pushed forward the principle that the Member States must take repressive steps also against own nationals. ${ }^{21}$

Another fundamental principle applicable in relation to the EU citizens, especially the long-term residents, is the requirement of integration in the host Member State. Simply put, the longer the free moving EU citizen stays in another Member State, the more integrated he/she is and the more protection against expulsion he/she should get. This principle is expressed in the Directive 2004/38 through the variable length of stay in the host Member State and rights acquired thereby. Consequently, an EU citizen with a right of permanent stay (after 5 years of legal residence in the host Member State) can be expelled only on serious grounds of public policy and public security, ${ }^{22}$ and a person staying in another Member State for more than 10 years could be expelled only on imperative grounds of public security. ${ }^{23}$ Thus, the threat to public security must be of a particularly high degree. ${ }^{24}$ By the requirement of a qualified threat to public security the Directive went beyond the wording of the EU primary law and in that sense curtailed the discretion of Member States.

It should be added that the highest degree of protection under art. 28 para 3 concerns only EU citizens and not their family members. Correspondingly family members (including those from third countries) could be expelled on "only" serious grounds of public security or public policy even if they stay in the host Member State for more than 10 years. The imperative character of their conduct is not required.

In recent decisions the CJEU seems to interpret the meaning of imperative grounds of public security in a more relaxed manner broadly. In Tsakouridis the

19 See already the Council Directive 64/221/EEC of 25 February 1964 on the co-ordination of special measures concerning the movement and residence of foreign nationals which are justified on grounds of public policy, public security or public health, Official Journal 056, 04/04/1964, p. $850-857$.

20 See 41/74 Van Duyn v Home Office, ECLI:EU:C:1974:133.

21 F.e. joined cases 115 and 116/81 Adoui and Cornuaille $v$ Belgian State, ECLI:EU:C:1982:183. For a survey of case-law see REICH, Norbert, HARBACEVICA, Solvita. Citizenship and Family on Trial: A Fairly Optimistic Overview of Recent Court Practice With Regard to Free Movement of Persons. Common Market Law Review, 2003, no. 3, vol. 40, p. 615-638.

22 See art. 28 para 2 of Directive 2004/38.

23 See art. 28 para 3 of Directive 2004/38.

24 Comp. C 145/09 Tsakouridis, ECLI:EU:C:2010:708, points 11-13. 
CJEU included in the imperative grounds also organised drug-related crimes. ${ }^{25}$ Even though the CJEU mitigated its decision by the requirement of a national court's assessment of the integration in the society ${ }^{26}$ and a due respect for right to family life $\mathrm{e}^{27}$ of the individual concerned, the judgment was criticised for obscuring the distinction of public policy and public security grounds as well as blurring the line between serious and imperative grounds of public security (second versus third paragraph of art. 28). ${ }^{28}$ The main outcome of Tsakouridis case may be read as an increased discretion for Member States to expel longterm resident citizens of other Member States.

This approach was later confirmed in P.I. ${ }^{29}$ where the CJEU accepted as imperative grounds of public security also sexual abuse of minors - differently to Tsakouridis case - without the person convicted being part of any organised structure. According to the CJEU this behaviour constituted a particularly serious threat to one of the fundamental interests of society, which might curb the calm and physical security of the population. The CJEU also admitted that other grounds of public security could be added. ${ }^{30}$ Even though this line of caselaw may not be fully convincing, ${ }^{31}$ it establishes a present state of law with an increase of Member States' discretion in the decisions on internal migration.

\subsection{Interim conclusions on internal market rules and EU citizenship}

The preceding analysis clarified that the intra-EU developments in CJEU migration decisions are crucial for the proper comprehension of the public security exception. The public security exception seems to be well settled in the EU internal market case-law, including free movement of persons and EU citizenship. The CJEU adopted a common concept of public security in all areas of EU law. It includes both internal and external (international) security of a Member State. Despite recent decisions relating to specific situations on the EU citizen-

25 See Tsakouridis, point 47.

26 See Tsakouridis, point 34-35.

27 See Tsakouridis, point 52.

28 See for statistics see KOSTAKOPOULOU-DOCHERY, Dora, FERREIRA, Nuno. Testing Liberal Norms: Public Policy and Public Security Derogations and the Cracks in European Union Citizenship. The Columbia Journal of European Law, 2014, vol. 20, 2014, p. 173. For more commentary see STEHLÍK, Václav. Metamorphosis of Public Security Exception in the EU Internal Market and EU Citizens' Rights. In: Agnieszka Bień-Kacała, Lóránt Csink, Tomasz Milej, Maciej Serowaniec (ed.). Liberal constitutionalism - between individual and collective interests. Toruń: Wydział Prawa i Administracji Uniwersytetu Mikołaja Kopernia w Toruniu, 2017, p. 232.

29 C-348/09 P. I., ECLI:EU:C:2012:300.

30 With the referral to art. 83 para 1 TFEU, see P.I., point 28.

31 A strong criticism was presented by Kochenov and Pirker who expect this line of case-law to be forgotten; see KOCHENOV, Dimitry, PIRKER, Benedikt. Deporting the Citizens within the European Union: A Counter-Intuitive Trend in Case C-348/09, P.I. V Oberburgermeisterin der Stadt Remscheid. The Columbia Journal of European Law, 2013, vol. 19 , issue 2, p. 373 
ship the CJEU requires that Member States' discretion to limit EU free market rules should be interpreted and applied narrowly and the decisions should not rest on economic considerations. In relation to persons any decision must be justified by a personal conduct of the individual who must be of a genuine, present and sufficiently serious threat affecting one of the fundamental interests of society.

The dominant tendency for this approach is understandable as any restrictions disrupt the idea of liberal market free of any unjustified interferences of Member States and particularly free of any discrimination based on nationality of all EU citizens wherever they want to settle. The question is whether these principles will be fully transferable also to the EU immigration rules.

\section{Interpretation of public security in selected EU acts on migration}

\subsection{Conceptual remarks}

The status of third country nationals is variable. The most prominent group includes family members of EU citizens whose status is split depending on whether the EU citizen used its right to free movement or not. The EU law is primarily ${ }^{32}$ concerned with the first situation. Correspondingly, family members of the free moving EU citizens have the right of entry and residence in other Member States as well as a number of other rights. ${ }^{33}$ As is firmly embedded in a huge volume of case-law, their rights are more extensive compared to other groups of third country nationals. The rules applicable in relation to exceptions including public policy and security are similar to those applicable to free moving EU citizens, except specific situations. ${ }^{34}$

The following analysis will primarily focus on the third country nationals whose status is governed by specific EU secondary legislation. It will concentrate on the Directive 2004/114 regulating rights of students from third countries ${ }^{35}$ including recent judicial developments. This concerns especially a CJEU deci-

32 However, since Zambrano the protection of third country national is not necessarily conditioned by the requirement of the cross-border movement of the EU citizen, see C-34/09 Ruiz Zambrano, ECLI:EU:C:2011:124 or C-434/09 McCarthy, ECLI:EU:C:2011:277. For a commentary see f.e. HAILBRONNER, Kay, THYM, Daniel. Case C-34/09, Gerardo Ruiz Zambrano v. Office national de l'emploi (ONEm), Judgment of the Court of Justice (Grand Chamber) of 8 March 2011, not yet reported. Common Market Law Review, 2011, 48, 2011, p. 1263-1270.

33 Much literature was written on this issue and, thus, it will not be directly referred to at this place; see f.e. BARNARD, Catherine. The EU Substantive Law of the EU: The Four Freedoms. Oxford: Oxford University Press, $5^{\text {th }}$ ed., 2016, p. 494-513.

34 This will include f.e. a lesser protection in relation to long-term residents under art. 28 para 3 of Directive 2004/38 as was already indicated.

35 Directive 2004/114/ EEC of 13 December 2004 on the conditions of admission of thirdcountry nationals for the purposes of studies, pupil exchange, unremunerated training or voluntary service, OJ 2004 L 375, p. 12. 
sion in Fahimian which directly involves public security concerns in the context of Directive 2004/114. As there are no other similar cases, this decision becomes an important and exclusive source of information. First, the factual and legal background of the case will be covered and, then, most important excerpts from the opinion of Advocate General and the decision of CJEU.

\subsection{Directive 2004/114 and public security in Fahimian case}

\section{Factual and legal background}

The Fahimian case $^{36}$ concerned an Iranian national who studied information technology in Teheran at the university which was on the list of entities subject to EU restrictive measures. ${ }^{37}$ She intended to study a doctorate at a German university with research focused on the security of mobile systems and especially on effective protection for smartphones. She was accepted for studies; however, her visa application was refused.

The subsequent judicial review of the decision initiated before German courts concerned primarily the interpretation of art. 6 (1) letter d) of the Directive 2004/114. According to this article a person who intends to come to the EU Member State for the purpose of studies must not be regarded as a threat to public policy, public security or public health. The national court put three questions to the CJEU which could be summarised as follows:

- how much discretion is left to Member States when they decide on the right of entry of a third country national

- what are the legal limits placed on national authorities when assessing that a third-country national is to be regarded as a threat to public policy, public security or public health based on the facts underlying that assessment and their evaluation

- how to assess the actual case concerning the situation of Ms. Fahimian, namely the grounds for refusal.

The fear of national authorities was that the skills acquired in connection with her research project might be misused in Iran. This could concern for instance the acquisition of sensitive information in Western countries for the purpose of internal repression or more generally in connection with human rights violations. ${ }^{38}$

\section{Opinion of Advocate General}

Before analysing the CJEU judgment it will be helpful to outline the opinion of AG Szpunar. He focused on several central questions, namely the concept of

36 C-544/15 Fahimian, ECLI:EU:C:2017:255.

37 See Annex IX to Council Regulation (EU) No 267/2012 of 23 March 2012 concerning restrictive measures against Iran and repealing Regulation (EU) No 961/2010, OJ L 88, 24.3.2012, p. 1-112

38 Comp. Opinion of AG in Fahimian, point 21. 
public security within the meaning of Directive 2004/114, extent of discretion available to national administrative and judicial authorities. ${ }^{39}$

The first issue was whether the Directive 2004/114 guarantees any right to entry the EU for third country nationals. According to AG Szpunar the first entry for the purpose of legal migration is a domain left to Member States. He analysed international law instruments, especial European Convention for the Protection of Human Rights and Fundamental Freedoms, and concluded that there is no right to enter a state, except for the requirement of non-refoulement in asylum law, ${ }^{40}$ family reunifications and the obligations of Member States to respect the right to family life. ${ }^{41}$ Similarly, the EU Charter of Fundamental Rights does not guarantee any right of entry; principally it requires merely the prohibition of discrimination based on nationality for third country nationals who are legal resident in the EU. ${ }^{42}$

AG Szpunar distinguished between EU rules for intra-EU and extra-EU migration. Primarily the migration law is linked to the functioning of the internal market which is characterised by the abolition of internal borders and common regime at the external borders. ${ }^{43}$ In this context the objective of Directive 2004/114 is to set up conditions and procedures for admission of third country nationals for the purpose of study. The rationale behind the Directive is to attract to the EU qualified third-country nationals; this aim being primarily economic and not the human rights protection. ${ }^{44}$ This reading of Directive 2004/114 is supported by an analysis of the new Directive that will replace the existing one in $2018 .{ }^{45}$ The aim of the new directive is particularly to attract highly skilled people in order to ensure growth, enrichment of migrants and their country of origin. It confirms the conclusion that it is not primarily a human rights dimension which stands behind this law. ${ }^{46}$

AG Szpunar further analysed the extent of Member States' discretion with a referral to preceding case-law, namely the decision in Ben Alaya. ${ }^{47}$ This case also concerned the entry to the EU for the purposes of study as understood by Directive 2004/114 and the refusal of entry visa. In this case German authorities

39 See ibid, point 25.

40 With referral to art. 3 of the Convention.

41 Ibid, art. 8 of the Convention.

42 Opinion of AG in Fahimian, point 29 referring to art 15 (3) and 45 (2) of the EU Charter.

43 Ibid, point 30.

44 In contrast to f.e. asylum law, comp. ibid point 33.

45 Directive 2016/801 of the European Parliament and of the Council of 11 May 2016 on the conditions of entry and residence of third-country nationals for the purposes of research, studies, training, voluntary service, pupil exchange schemes or educational projects and au pairing, OJ L 132, 21.5.2016, p. 21-57. This directive will replace the current directive since May 25, 2018.

46 Comp. Opinion of AG in Fahimian, points 35-36.

47 C-491/13 Ben Alaya, ECLI:EU:C:2014:2187. 
tried to create a new condition for the entry other than those conditions enumerated in art. 6 and 7 of the Directive. This was refused by the CJEU in Ben Alaya.

Next AG Szpunar focused on the definition of public security in the EU law. He concluded that public security grounds are used both in internal market as well as EU citizenships rules; however, Member States keep their power to formulate public security concerns according to their needs. Still, any recourse to the public security restrictions is limited by a control of EU institutions. There is not a common definition of public security, but the concept was clarified in the case-law of the CJEU. ${ }^{48}$ As the definition of public security is wide, AG Szpunar accepts that security aspects of an international and external relations should therefore be covered thereby and was ready to accept objections of German authorities against Ms. Fahimian in that regard. ${ }^{49}$

AG Szpunar analysed the internal market rules requiring that any expulsion justified by public security must be based on the personal conduct of the individual concerned. In EU internal situations any decisions reasoned by general preventive grounds are not acceptable and the person must be a genuine, present and sufficiently serious threat affecting one of the fundamental interests of society ${ }^{50}$ This approach is not valid for external border regime, including Directive 2004/114. AG Szpunar substantiated his reasoning on several aspects, especially on different wording and construction of internal market rules and Directive 2004/114, legislative process leading to the adoption of Directive 2004/114 and Directive 2004/38 and on a differing legal basis. ${ }^{51}$

Finally, when assessing the range of discretion of national authorities AG Szpunar took into consideration the problem of fact-finding in relation to a third country and admitted a broad discretion in that regard. The condition that any decision on expulsion must be based strictly on a person conduct should not be required; still, there must be a link between the person and the measure taken. The individualisation of the issue is less stringent in more sensitive issues. ${ }^{52}$

The Opinion of AG Szpunar is convincing and well argued. It searches for the rationale of the EU regulation of both internal and external migration. It distinguishes them and clearly calls for a broad discretion for Member States.

\section{Decision of the CJEU}

In comparison to opinion of AG Szpunar the decision of the CJEU is more laconic. It comes out of the necessity to consider both the wording and the con-

48 Szpunar then refers to the structural elements of public security in previous case, see Opinion, point 52 .

49 See Opinion of AG in Fahimian, point 53.

50 Comp. ibid, point 55.

51 Comp. ibid, points 58-61.

52 Comp. ibid, points 68-69. 
text of the contested EU Directive. ${ }^{53}$ Member States cannot add any conditions for entry of students from third countries other than those enumerated in art. 6 and 7 of the Directive. However, national authorities have a margin of discretion when assessing the fulfilment of these conditions, including public security considerations. $^{54}$

As the Directive 2004/114 does not explicate the concept of public security, the CJEU repeated the definition as was formulated in the previous case-law. ${ }^{55}$ Thereby the CJEU confirmed that the definition is common both to internal and external dimension of the EU migration regulation. However, the CJEU further differentiated between the internal migration covered by the Directive 2004/38 and immigration based on Directive 2004/114. Whereas the former rests on the necessity to consider a real threat to public security based on the evaluation of personal conduct of the individual concerned, in case of Directive 2004/114 it is sufficient that the person concerned constitutes only a potential threat. This is assessed on the facts of the case founded on not only the personal conduct of the applicant but also other elements relating, in particular, to his professional career. ${ }^{56}$

The crucial instructions to national authorities were articulated in point 41 of the judgment, according to which an assessment of visa applicant may involve complex evaluations based inter alia on the personality of that applicant, his integration in the country where he resides, the political, social and economic situation of that country, and the potential threat to public security... in view of the risk that the knowledge acquired by that applicant during his studies might subsequently be used in his country of origin for purposes prejudicial to that public security. This assessment involves predicting the foreseeable conduct of the applicant for the visa, and must be based inter alia on an extensive knowledge of his country of residence and on the analysis of various documents and of the applicant's statements. ${ }^{57}$

National authorities, thus, have a wide discretion to assess the relevant facts of the case and subsequent judicial review of administrative decisions is limited to the manifest errors in the administrative procedure and safeguarding procedural guarantees, including a proper justification of the decision..$^{58}$

53 Comp. CJEU in Fahimian, point 30.

54 Ibid, points $33-37$.

55 With a referral to Tsakouridis case.

56 See Fahimian, point 40.

57 See ibid, point 41.

58 See ibid, points $42-46$. 


\section{Broader perspective of public security concerns in EU external migra- tion law}

\subsection{Member States' discretion in secondary legislation}

The decision in Fahimian confirmed the distinction between internal and external migration. As was already shown the EU internal migration should be free of any unfounded obstacles and any restriction must be interpreted strictly. This overall approach is applicable in all market freedoms and also EU internal migration, namely EU citizenship. This does not mean that there would be no discretion for Member States to decide on public security/policy concerns in an individual case. However, their use ought to be strictly proportionate and properly justified.

In Fahimian the CJEU relies on the contextual interpretation of the EU migration rules. This is actually not a new approach and in the context of external treaties was set up by the CJEU much earlier. ${ }^{59}$ The rule is that the legal concepts used in provisions appearing in EU external instruments are not interpreted necessarily in the same way as mirror provisions in the EU internal market. ${ }^{60}$ This allows the CJEU to adapt its interpretation in external context based on the differing objectives of the legal acts concerned. The rationale behind Directive 2004/114 is primarily economic with benefits both for the EU and also the person coming to the EU which does not justify any unconditional right to come to the EU. ${ }^{61}$ Consequently, the CJEU could chose a more sensitive approach to public security concerns of Member States.

A similar motivation can be found behind other categories of third country nationals coming to the EU under other directives adopted with the perspective to increase the competitiveness of the EU in the world. This concerns namely researchers who are covered by the Directive 2005/71. ${ }^{62}$ This Directive is construed in parallel to Directive 2004/114 and also includes a condition that a person concerned may not pose a threat to public policy, public security or public

59 And also confirmed by a referral to Fahimian in later cases, see f.e. 605/15 Aviva, ECLI:EU:C:2017:718, point 24 or C-616/15 Commission v Germany, ECLI:EU:C:2017:721, point 43.

60 Compare in that regard 270/80 Polydor and Others $v$ Harlequin and Others, ECLI:EU:C:1982:43, esp. point 15.

61 In that regard see also an analysis of Directive 2004/114 in HOOGENBOOM, Alexander. Turkish Nationals and the Right to Study in the European Union: A Progressive Interpretation. European Journal of Migration and Law, 2013, vol. 15, issue 4, especially p. 114 et seq. Hoogenboom reflects on the issue whether in case of complying with all requirements in the Directive, the student has the right of entry and residence or whether the Member States still enjoy a discretion in that regard.

62 Council Directive 2005/71/EC of 12 October 2005 on a specific procedure for admitting third-country nationals for the purposes of scientific research, OJ L 289, 3.11.2005, p. $15-22$ 
health. ${ }^{63}$ The common approach to both students and researchers is even more evident due to the fact that both these directives will be soon replaced by a single directive. Additionally an analogous approach was adopted in Directive 2009/50 covering the regular immigration such as high qualified workers. ${ }^{64}$ Likewise the public policy and security appears in the Directive 2003/109 which governs the rights of third country nationals who are already legally resident in the EU. The status of a long-term resident may be refused on public policy and security grounds. This Directive requires that the decision must be based on individualised considerations. ${ }^{65}$

The new consolidating Directive 2016/80166 covers various categories of third country nationals coming to the EU and replaces both Directive 2004/114 and Directive 2005/71. It preserves the condition that the person intending to come to the EU should not pose a threat to public policy, public security or public health. ${ }^{67}$ It is even more specific in its preamble according to which an admission of a third country national will be refused if the third-country national is only a potential threat to public policy, public security or public health. This assigns a much broader discretion to Member States and their authorities which was adjudicated in relation to currently valid directive where no mention on potential threat appears.

\subsection{Member States' discretion in EU external agreements}

Public policy and security provisions are often inserted also in external agreements that the EU concludes with third countries. We may refer to the Europe Agreements which were the basic documents establishing the association of Central and Eastern European countries before their accession to the EU. The CJEU accepted a strict reading of exceptions based on public policy and ruled similarly to internal market rules that the third country nationals must constitute a genuine threat to public order. It required that the same effective

63 Art. 7 (1), letter d.

64 See art. Art. 5 (1), letter f) of Council Directive 2009/50/EC of 25 May 2009 on the conditions of entry and residence of third-country nationals for the purposes of highly qualified employment, OJ L 155, 18.6.2009, p. 17-29.

65 Comp. Art. 6 para 1 of the Directive which was inspired by former Directive 64/221, in that regard see f.e. BOELAERT-SUOMINEN, Sonja. Non-EU Nationals and Council Directive 2003/109/EC on the Status of Third-Country Nationals Who are Long-Term Residents: Five Paces Forward and Possible Three Paces Back. Common Market Law Review, 2005, 42, p. 1032 et seq.

66 Directive (EU) 2016/801 of the European Parliament and of the Council of 11 May 2016 on the conditions of entry and residence of third-country nationals for the purposes of research, studies, training, voluntary service, pupil exchange schemes or educational projects and au pairing, OJ L 132, 21.5.2016, p. 21-57.

67 Art. 7, para 6. 
measures to monitor and repress activities must be taken by Member States also to its own nationals. ${ }^{68}$

An analogous approach was adopted in relation to the EU-Turkey Association Agreement and the Decision of the Association Council ${ }^{69}$ implementing the provisions of the agreement on the movement to workers. ${ }^{70}$ There the CJEU concluded that the Association Agreement and the Decision should be as far as possible interpreted in the same way as mirror provisions in the EU law. ${ }^{71}$ This approach is prima facie strongly oriented on the non-discrimination principle of persons covered by the association agreements. In recent case law it was accepted that the public interest concerns may be used by Member States, among others, to react to the migration crisis. The CJEU confirmed a degree of discretion in deciding on the right of residence to efficiently manage of migration flows. ${ }^{72}$

The same conclusions as adopted in the internal market rules seem to be applicable in relation to the Agreement on the European Economic Area. This agreement is based on the participation of EFTA countries (except Switzerland) on the internal market including free movement of persons. In relation to the free movement of workers the EEA Agreement sets up the right for Member States to limit the free movement based on public security (as well as public policy and public health) concerns. In this respect the provisions of EEA Agreement fully mirror the corresponding rules in the EU primary law. ${ }^{73}$ This covers free movement of goods, ${ }^{74}$ workers, ${ }^{75}$ establishment or $^{76}$ provision of services. ${ }^{77}$ Furthermore, the EFTA countries bound by the EEA ${ }^{78}$ are obliged to take over the EU legislation in internal market, ${ }^{79}$ including Directive 2004/38 ${ }^{80}$ which regulates the application of public policy as well as public security.

68 Comp. C-268/99 Jany and Others, ECLI:EU:C:2001:616, point 61.

69 Decision No $1 / 80$ of the Association Council of 19 September 1980 on the development of the Association.

70 C-340/97 Nazli and Others, ECLI:EU:C:2000:77.

71 See ibid, point 55.

72 See f.e. C-652/15 Tekdemir, ECLI:EU:C:2017:239.

73 The interpretation of mirror provision should be the same in case they are identical in substance, see in this regard C-522/04 Commission v. Belgium, ECLI:EU:C:2007:405, points 43-44, and a commentary in EISELE, Katharina. The External Dimension of the EU's Migration Policy. Leiden: Brill/Nijhoff, 2014, p. 209.

74 See EEA Agreement, art. 13.

75 See ibid, art. 28.

76 See ibid, art. 33.

77 See ibid, art. 39 with referral to art. 33.

78 Norway, Island and Liechtenstein, except Switzerland.

79 Comp. EEA Agreement art. 7, for more see also STEHLIK, Václav. Brexit, EEA and the free movement of workers: structural considerations on flexibility. International and Comparative Law Review, 2016, vol. 16, no. 2, 2016, pp. 148-152, available at: https://www.researchgate.net/publication/322704701_Brexit_EEA_and_the_Free_Movement_of_Workers_ Structural_Considerations_on_Flexibility.

80 See EEA Agreement, Annex V, point 1. For a commentary on the homogeneity rules in the 
Finally, public security concerns were reflected f.e.in the CETA agreement ${ }^{81}$ between the EU, its Member States and Canada. This agreement contains a general exception from the application of its provisions, including movement of persons, and allows restrictions justified by public security, public morals or to maintain public order. ${ }^{82}$ Interestingly when applying public security and public order exceptions this agreement explicitly requires that there must be a genuine and sufficiently serious threat to one of the fundamental interests of society. ${ }^{83}$ This echoes conditions of Directive 2004/38 and, potentially, also predicts the importance of the interpretation already given by the CJEU; certainly again with the reservation of the context-related interpretation.

\section{Conclusions}

The main focus of the article was to analyse the concept of public security and its use in EU migration rules, especially as concerns the level of discretion attributed to the Member States. It may be concluded that there is no common definition of public security in written EU law and, consequently, it has been delineated particularly in the EU internal market case-law. When interpreting the term, the CJEU cross-refers to cases dealing with all market freedoms and uses it also in external relations.

Whereas the concept itself seems to be universally applicable, the extent of discretion given to Member States in individual areas is variable. The narrowest discretion seems to be in the ambit of internal market rules, though with some shift in recent developments as was demonstrated in Tsakouridis and P.I.. A comparable approach developed in relation to agreements with third countries setting up privileged relations to the EU. This includes Europe agreements, EEA Agreement, as well as recent agreements such as CETA. The level of scrutiny copies or is very similar to that adopted in the context of the internal market rules. Still, in this regard it is necessary to bear in mind the context-related interpretation founded on the comparison of the objectives of the external treaty and the rule of the EU internal market. Then a partially differing interpretation cannot be excluded. ${ }^{84}$

EEA Agreement see f.e. BAUDENBACHER, Carl. The Judicial Dimension of the Europe. College of Europe: EU Diplomacy Paper, No. 8, 2013, available at: available at: https://www. coleurope.eu/study/eu-international-relations-and-diplomacy-studies/research-activities/ eu-diplomacy-papers.

81 Comprehensive Economic and Trade Agreement, accessible and explained at http:// ec.europa.eu/trade/policy/in-focus/ceta/.

82 Comp. art. 28.3 para 2 letter a) of CETA Agreement.

83 See the CETA Agreement and footnote number 31 related to art. 28.3 para 2 letter a).

84 For a detailed analysis see f.e. TOBLER, Christa. Context-related Interpretation of Association Agreements. The Polydor Principle in a Comparative Perspective: EEA Law, Ankara Association Law and Market Access Agreements between Switzerland and the EU, In: Daniel Thym, Margarite Zoeteweij-Turhan (eds). Rights of third-country nationals under EU Association Agreements. Leiden: Brill/Nijhoff, 2015, p. 101-126 
In relation to mmigration based on Directive 2004/114 the discretion of Member States showed to be much broader. Correspondingly the refusal of entry may be founded on merely a potential threat of the person to public security. This approach appears to be applicable likewise in relation the Directive 2005/71 or the new Directive 2016/801.

Finally, it should be recalled that the actual application of public security concerns in individual cases will depend on other complex aspects. This concerns foremostly the right to family life, reunification of families or level of integration into the society of Member States. This may substantially influence the discretion of Member States and the outcomes of the cases.

\section{References}

BARNARD, Catherine. The EU Substantive Law of the EU: The Four Freedoms. Oxford: Oxford University Press, $5^{\text {th }}$ ed., 2016

BAUDENBACHER, Carl. The Judicial Dimension of the Europe. College of Europe: EU Diplomacy Paper, No. 8, 2013, available at: <https://www.coleurope.eu/study/euinternational-relations-and-diplomacy-studies/research-activities/eu-diplomacypapers> Accessed: 30.11 .2017

BOELAERT-SUOMINEN, Sonja. Non-EU Nationals and Council Directive 2003/109/EC on the Status of Third-Country Nationals Who are Long-Term Residents: Five Paces Forward and Possible Three Paces Back. Common Market Law Review, 2005, 42, pp. $1011-1052$

EISELE, Katharina. The External Dimension of the EU's Migration Policy. Leiden: Brill/ Nijhoff, 2014

HAILBRONNER, Kay, THYM, Daniel. Case C-34/09, Gerardo Ruiz Zambrano v. Office national de l'emploi (ONEm), Judgment of the Court of Justice (Grand Chamber) of 8 March 2011, not yet reported. Common Market Law Review, 2011, 48, 2011, pp. 1253-1270,

HOOGENBOOM, Alexander. Turkish Nationals and the Right to Study in the European Union: A Progressive Interpretation. European Journal of Migration and Law, 2013, vol. 15 , issue 4 , pp. 387 - 412

KOCHENOV, Dimitry, PIRKER, Benedikt. Deporting the Citizens within the European Union: A Counter-Intuitive Trend in Case C-348/09, P.I. V Oberburgermeisterin der Stadt Remscheid. The Columbia Journal of European Law, 2013, vol. 19, issue 2, pp. 369- 390

KOSTAKOPOULOU-DOCHERY, Dora, FERREIRA, Nuno. Testing Liberal Norms: Public Policy and Public Security Derogations and the Cracks in European Union Citizenship. The Columbia Journal of European Law, 2014, vol. 20, 2014, p. 167-191.

LENAERTS, Koen. 'Civis europaeus sum': from the cross-border link to the status of citizen of the Union. Online Journal on Free Movement of Workers within the European Union, 2011, no 3, pp. 6-18

REICH, Norbert, HARBACEVICA, Solvita. Citizenship and Family on Trial: A Fairly Optimistic Overview of Recent Court Practice With Regard to Free Movement of 
ICLR, 2017, Vol. 17, No. 2.

Persons. Common Market Law Review, 2003, no. 3, vol. 40, pp. 615-38

STEHLIK, Václav. Brexit, EEA and the free movement of workers: structural considerations on flexibility. International and Comparative Law Review, 2016, vol. 16, no. 2, 2016, pp. 145-156

STEHLÍK, Václav. Metamorphosis of Public Security Exception in the EU Internal Market and EU Citizens' Rights. In: Agnieszka Bień-Kacała, Lóránt Csink, Tomasz Milej, Maciej Serowaniec (ed.). Liberal constitutionalism - between individual and collective interests. Toruń: Wydział Prawa i Administracji Uniwersytetu Mikołaja Kopernia w Toruniu, 2017

TOBLER, Christa. Context-related Interpretation of Association Agreements. The Polydor Principle in a Comparative Perspective: EEA Law, Ankara Association Law and Market Access Agreements between Switzerland and the EU, In: Daniel Thym, Margarite Zoeteweij-Turhan (eds). Rights of third-country nationals under EU Association Agreements. Leiden: Brill/Nijhoff, 2015 